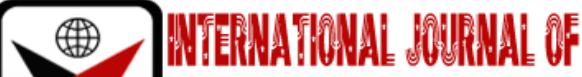

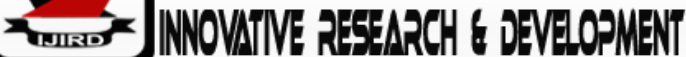

ISSN 2278 - 0211 (Online)

\section{To Determine the Relationship between Differentiation Strategy and Performance of Dairy Cottage Industries in Kiambu County, Kenya}

\begin{tabular}{c} 
Henry Mwithaga Kaara \\
Ph.D. Student, Department of Entrepreneurship, Technology, Leadership and Management, \\
Jomo Kenyatta University of Agriculture and Technology, Kenya \\
Iravo M. Amuhaya \\
Lecturer, Department of Entrepreneurship, Technology, Leadership and Management, \\
Jomo Kenyatta University of Agriculture and Technology, Kenya \\
Margaret A. Oloko \\
Lecturer, Department of Business Administration, \\
Jomo Kenyatta University of Agriculture and Technology, Kenya \\
Gichuhi A. Waititu \\
Lecturer, Department of Statistics and Actuarial Sciences \\
Jomo Kenyatta University of Agriculture and Technology, Kenya \\
\hline
\end{tabular}

\begin{abstract}
:
The dairy cottage industries in Kiambu County in Kenya have not achieved high performance of their businesses with respect to profit; in terms of market share, customer retention and sales volume amongst others. As such, the main purpose of the study was to determine the relationship between differentiation strategy and performance of dairy cottage industries in Kiambu County, Kenya. The study utilized a descriptive cross sectional survey research design, using both quantitative and qualitative research approach. The target population comprised of 162 study sample and a research sample size of 114 dairy cottage industries in Kiambu County. Stratified sampling was used to divide Kiambu County into 12 Sub-Counties (or strata). Structured and unstructured questionnaire was used for data collection from the target population. The instrument was pre-tested using the Cronbach's alpha value to determine the validity and reliability of the tests. Data collected from the field, both quantitative and qualitative in nature, was analyzed using the Statistical Package for Social Science (SPSS) Version 21. Quantitative data was analysed using inferential and simple descriptive statistics. Qualitative data analysed was presented using frequency distribution tables and histograms. The study utilized Exploratory Factor Analysis (EFA) statistical procedure, a technique within Factor Analysis (FA) to determine the number of latent variables that are needed to elucidate the correlations between latent variables and observed variables. The descriptive statistical technique of Principle Component Analysis (PCA) was utilized in identifying patterns in data to highlight their similarities and differences. Further, PCA was utilized to reduce the dimensionality of huge data sets in an attempt to compress the masses of data into fewer factors for ease of analysis. Correlation analysis as well as regression model were also applied to determine the relationship between differentiation strategy and performance of dairy cottage industries in Kiambu County, Kenya. The study revealed that differentiation strategy is an integral aspect of firm management. The study concluded there was significant relationship between differentiation strategy and performance of dairy cottage industries in Kiambu County. This study recommends that the proprietors of the dairy cottage industries in Kiambu County, Kenya should put some efforts on differentiation dimensions that is; brand image and products features, and service differentiation to improve on performance of their dairy cottage industries in Kiambu County, Kenya.
\end{abstract}

Keywords: Differentiation strategy, factor analysis, exploratory factor analysis, principal component analysis, performance of dairy cottage industries

\section{Back Ground of the Study}

Cottage industry is of great significance for the people living in the middle-income countries since it enhances their social economic status. Specifically, it makes a significant role towards development of emerging countries (Rahman \& Kumar, 2018). Social economic analysis and practical experience in many countries show that the cottage industries have displayed remarkable persistence and have contributed significantly to the social economic development of many countries (Hossain \& Imran, 2019; Tasneem\& Biswas, 2014). Despite many governments policies the support for 
enhancing the capacity of small-scale business, there has been little progress in eliminating challenges that are facing emerging cottage industries in many developing countries (Nagar \& Solanki, 2015). These industries provide products for rural and urban populations and also give employment opportunities and contribute to development (Makokha, 2014; Joy \&Kani, 2013; Khan, 2018). Cottage industries are especially important in the context of employment opportunities, equitable distribution of national income, for both rural and semi-urban areas (Pandey, 2013;Aluvala, 2017). They provide and facilitate effective mobilization of resources such as adequate capital and skills which might otherwise remain unutilized if these cottage industries were not there (Shivani, 2013; Bouazza, 2015). Nassiuma \& Nyoike (2014), note that the dairy sector in Kenya has resulted in expanded employment in different regions of the country through the establishment of milk processing plants and also the dairy associated industries. Through the sale of milk, farmers are able to generate financial resources and this has enabled them to raise their quality of life in general (Nassiuma\&Nyoike, 2014).

In Kenya, the growth in small-scale dairy cattle farming sector has seen a rise in the number of dairy cottage industries. These cottage industries are basically home-based units of production which rely on milk as the main raw material, and whose labor force consists of family units or individuals working at home with their own equipment's or animal-propelled skills (Tasneem\& Biswas, 2014). The dairy cottage industries specialize in milk and milk products such as fresh milk, pasteurized milk, yoghurt, flavoured milk, milk shake, cheese, and sour milk as reported by United States Agency for International Development (USAID, 2015) and (Kariuki, 2016). The Kenya Dairy Board (KDB), the body charged with regulating the dairy industry in Kenya, gives licenses to dairy cottage industries in order to formalize them (Kariuki, 2016). The dairy sector in Kenya contributes 14 per cent of agricultural Gross Domestic Product (GDP) and about 4 per cent of national GDP (Muthui, Mshenga\&Bebe, 2014).

\section{Statement of the Problem}

In developing countries, cottage industries are especially important in the context of employment opportunities, equitable distribution of national income, balanced regional growth and development of rural and semi-urban areas (Pandey, 2013). This sector is considered to be an engine of growth, especially in developing countries due to their contribution to income generation, employment, Gross Domestic Product (GDP) and export earnings (Bouazza, 2015). The major problem that was addressed in this study was that, as reported by Kenya National Bureau of Statistics (KNBS) (KNBS, 2016), a majority of the cottage-based businesses firms in Kenya have not achieved high performance in terms of; market share, customer retention and sales volume amongst others. Indeed, some studies indicate a decline by $10 \%$ in profit for family businesses dealing in dairy and its products (Wambugu, Kirimi\&Opiyo, 2011). A number of studies confirm that a majority of the cottages industries have embraced differentiation strategy (Atikiya, Mukulu, Kihoro \& Waiganjo, 2015; Dirisu, Iyiola\&Ibidunni, 2013; Mwangi\&Ombuni, 2013; Pourhosseini\&Shahrokh, 2013). Yet, many of them have not satisfactorily addressed low performance arising from fluctuating supply of raw materials, marketing problems, lack of managerial talent, and competition with large-scale companies (Joy \&Kani, 2013; Mbugua, Njeri\&Ondabu, 2014; \&Makokha, 2015). This leads to the question: does embracing of differentiation strategy lead to improved performance in dairy cottage industries as has been evidenced in research conducted among large scale industries? The current study will address itself to this research problem.

The problem is further compounded by deficiency of information on the relationship between differentiation strategy and performance of dairy cottage industries, despite a number of studies having been done as indicated above. Moreover, as noted in 75\% majority of the references, many studies in this area have been conducted within the context of developed nations such as USA, Europe amongst others mainly focusing on large and manufacturing industries (Aluvala, 2017).In spite of the adoption and improved management strategies, many of the cottage-based industries have continued to perform poorly (Mbugua, Njeru\&Tirimba, 2014). Indeed, recent statistics (KNBS, 2016), indicate that an estimated total of 2.2 million Micro Small and Medium Enterprises (MSMEs) in Kenya were closed, a majority of which were cottage-based businesses. A number of studies and reports have largely attributed the underperformance to fluctuating supply of raw materials, marketing problems, lack of managerial talent, and competition with large-scale companies (Joy \&Kani, 2013; Mbuguaet al., 2014 and Makokha, 2015). It is in line with foregoing that this study sought to determine the relationship between differentiation strategy and performance of dairy cottage industries in Kiambu County, Kenya. The study provided knowledge on information gap related to the relationship between differentiation strategy and performance of dairy cottage industries in Kiambu Count, Kenya.

\section{Specific Objective}

To determine the relationship between differentiation strategy and performance of dairy cottage industries in Kiambu County, Kenya

\section{Research Hypotheses}

\subsection{Null Hypothesis}

- $\quad \mathrm{H}_{1}$ : There was no significant relationship between differentiation strategy and performance of dairy cottage industries in Kiambu County, Kenya.

\subsection{Alternate Hypothesis}

- $\mathrm{HO}_{2}$ : There was a significant relationship between differentiation strategy and performance of dairy cottage industries in Kiambu County, Kenya. 


\section{Literature Review}

\subsection{Differentiation Strategy}

Differentiation strategy is defined as one in which a product is different from that of one or more competitors in a way that is valued by the customers or in some way affects customer's choice (Becerra, Santaló\& Silva, 2013). A successful differentiation strategy allows firm to earn above the average returns. In this study, the dimensions of differentiation strategy included brand image and products features (introduces innovative and unique products, continuously developing new products, use superior packaging of products, always offer a broad range of products), and service differentiation (offering unique customers experience and investing in research and development). Brand image refers to the sum of a customer's perceptions about a brand generated by the interaction of the cognitive, affective, and evaluative processes in a customer's mind (Lee, Jeffrey \& Kim, 2014). Brand image forms the basis for making better strategic marketing decisions about targeting specific market segments and positioning a product. Managers attempt to seek, select, sustain, and support a positive and unique brand image in order to differentiate one's brand from the others (Lee et al., 2014). Cottage industries can attain differentiation strategy by ensuring that their products are of superior quality than that of the competitors by having superior products features. Research by Nguyen \&Gunasti (2018) has shown that, by pursuing superior products features, the power of brand identity cues can help original brands to reduce share loss to copycat brands.

Differentiation also refers to the development of a unique products or services (Wang, Lin \& Chu, 2011). These products are seen as such when compared with competing products because of the distinguished features. The strategy involves uniqueness in doing something that is sufficiently valued by customers to allow a price premium (Kinyuira, 2014). The emphasis can be on brand image, superior products features, service differentiation, a strong distributor network or other aspects that might be specific to an industry. The uniqueness should also translate to profit margin that is higher than the industries average (Wang et al., 2011).

Differentiation is when a firm or brand outperforms rival brands in the provision of a feature(s) such that it faces reduced sensitivity for other features (Kotelnikov, 2013). While there are numerous ways to differentiate brands, identifying meaningful product-driven differentiators can be especially fruitful in gaining and sustaining a competitive advantage (Dirisu, Iyiola \& Ibidunni (2013). The advantages attained through differentiation are more likely to be sustainable because unique service or products valued by customers cannot be easily imitated by competitors (Banker, Mashruwala \& Tripathy, 2014). Moreover, a focus on making reliable and high-quality products will have a significant impact on sales, especially in more mature industries or in industries in which there is a high cost of poor performance (Wang et al., 2011). Firms that focus on differentiation often rely on product customization which, in turn, involves depending on close relationships developed with those customers. These close relationships overtime build the reputation of the firm (Banker et al., 2014). Companies that excel in developing close relationships with customers build customer loyalty for the long term (Hoyer, MacInnis \& Pieters, 2014). This is turn enables such companies to achieve sustainable financial performance in the long run.

Performance refers to output of an organization which can be measured both financial and non-financial measures such as products' quality, price in terms of competitiveness or outcomes such as profit (Awaluddin, Sule \&Kaltum, 2016). Performance of dairy cottage industries in this study was measured using the following three indicators; market share (we have a self-rating system for our business unit's overall market share objective and we enjoy a large market share with our products sales), customer retention (the business has experienced customer royalty or repeat customers) and sales volume (the enterprise has experienced an increase on average in daily sales). Market share refers to that portion of a market controlled by a particular company or product. By nature, cottage industries are expected to control a smaller market share within a limited geographical region (Hemedi, 2019). Customer retention refers to the activities and actions of companies and organizations to reduce the number of customer defections and making them loyal (Kebede \& Tegegne, 2018). The goal of customer retention programs is to help companies retain as many customers as possible, often through customer loyalty and brand loyalty initiatives. The third indicator of performance is sales volume, which simply means the amount of a given product sold to the market for a given time period (Utami, 2015). The survival and growth of every business is largely dependent on the adoption and implementation of appropriate strategies (Agyapong, Ellis \&Domeher, 2016). According to Porter (1985), through strategies, the core competence of businesses is identified, prioritized, and exploited for the purposes of reaching the organization's core objectives.

\section{Research Design}

The study employed a descriptive cross sectional survey design, using both quantitative and qualitative research approaches to determine the relationship between differentiation strategy and performance of dairy cottage industries in Kiambu County, Kenya. Descriptive survey, according to Groves, Fowler, Couper, Lepkowski, Singer \&Tourangeau (2011), research designis a systematic method for gathering information from a sample of entities for the purpose of constructing quantitative descriptors of the attributes of the larger population of which the entities are members. Thus, descriptive surveys describe phenomena associated with a subject population and/or estimate proportions of the population that have certain characteristics (Akporhonor \& Akpojotor, 2016).

\section{Sampling Frame}

Sampling frame refers to the set of source materials from which the sample is selected, and the purpose of sampling frames is to provide a means for choosing the particular members of the target population that are to be involved in the survey (Gichinga, Mukulu\&Mwachiro, 2014). In this study, the sampling frame included all the approximately 162 
licensed dairy cottage industries in Kiambu County, Kenya. Kiambu County has 12 Sub-Counties namely: Gatundu North, Gatundu South, Githunguri, Juja, Kabete, Kiambaa, Kiambu, Kikuyu, Lari, Limuru, Ruiru, and Thika. Thus, stratified sampling was used to divide Kiambu County into 12 Sub-Counties (or strata). Stratified sampling is appropriate when respondents are widely dispersed over a wide geographical area; the strata should be large enough to sample the entire region adequately (Kariuki, 2016). Names and contacts of the dairy cottage industries involved in the current study were obtained from the Kenya Dairy Board (KDB) office and Kiambu County Livestock, Fisheries and Veterinary Services office.

\section{Sample Size}

Sampling is the selection of a subset of individuals from within a population to yield some knowledge about the whole population, especially for the purposes of making predictions based on statistical inference (Bornstein, Jager, \&Putnick, 2013). Its main advantages are cost, speed, accuracy and quality of the data (Neuman 2013). From the target population of 162 dairy cottage industries, a representative sample was determined using the formula by Krejcie\& Morgan (2016), which was used to calculate a sample size (S), from a given finite population (P) such that the sample would be within plus or minus 0.05 of the population proportion with a 95 per cent level of confidence. Sample size determination has been studied by a number of social scientists (Kusi, Opata\&Narh, 2015; Coakes, 2013; Hair, Black, Babin, Anderson \&Tatham, 2013). Trotter, (2012), observes that a 15\% sample would be sufficiently representative for a multivariate analysis, as it takes into account the relatively high research costs of collection of data from spatially dispersed sampling units. Hair et al., 2013), however, recommend that as a rule for applying factor analysis the sample size has to be at least five times the number of variables to be analyzed. Coakes (2013) on the other hand propose a minimum of five subjects per variable. Based on the foregoing recommendations the current study's sample size of 114 dairy cottage industries was thus adequate for a multivariate analysis. Moreover, the sample size was larger than 30 recommended for a normally distributed population (Kothari, 2013). This formula is presented below:-

Where: $\quad \mathrm{S}=\mathrm{Z}^{2} N P(1-P) \div d^{2}(N-1)+\mathrm{Z}^{2} P(1-P)$

$\mathrm{S}=$ Sample size

$\mathrm{Z}=\mathrm{Z}$-score at $95 \%$ confidence level (1.96)

$\mathrm{N}=$ the population size, in this case 162 dairy cottage industries

$\mathrm{P}=$ the population proportion (assumed to be 0.5 since this would provide the maximum sample size)

$\mathrm{d}=$ the degree of accuracy expressed as a proportion (0.05)

Using this formula, the sample size was computed as follows:-

This gives:

$$
\begin{aligned}
& S=1.96^{2} \times 162 \times 0.5(1-0.5) \div 0.05^{2}(162-1)+1.96^{2} \times 0.5(1-0.5) \\
& S=155.52 \div 1.3625=114
\end{aligned}
$$

\section{Analytical Model}

$\mathrm{Y}=\beta 0+\beta 1 \mathrm{X}_{1}+\varepsilon$

$\mathrm{Y}=$ Dependent Variable: Performance of dairy cottage Industries

$\beta 0=$ Constant

$\beta 1=$ Regression coefficient for $\mathrm{Xi}(\mathrm{i}=1,2$,

$\mathrm{X}_{1}=$ Differentiation strategy

$\varepsilon=$ Error term

\section{Response Rate}

\begin{tabular}{|c|c|c|}
\hline Response Status & Number & Percentage (\%) \\
\hline Responded & 98 & 86 \\
\hline Did Not Respond & 16 & 14 \\
\hline Total & 114 & 100 \\
\hline
\end{tabular}

Table 1: Response Rate

Table 1 indicates that out of the 114 questionnaires administered, 98 were returned. The overall response rate was thus found to be $86 \%$ which was very high. Sixteen (16) questionnaires administered were not returned which represented $14 \%$ of the targeted respondents in dairy cottage industries. The interpretation was that the high response rate was essential to obtain sufficient observations for further analysis. Kothari (2013) asserts that a response of above $50 \%$ increases accuracy and representativeness of the findings. 


\section{Research Findings and Discussion}

\subsection{Data Analysis for Study Variables}

To measure the suitability of the data for Factor Analysis (FA), Kaiser-Meyer-Olkin (KMO) Measure of Sampling Adequacy was used to measure the sample adequacy of every variable construct in the study. High values (close to 0.1) generally indicate that FA may be useful in the study data. KMO measurer of sampling adequacy should be greater than 0.5 for satisfactory FA to be executed (Burns \& Burns, 2008). Ali, Namusonge\&Sakwa (2016), states that the KMO index ranges from 0 to 1, with 0.5 and above are considered suitable for FA. The Bartlett's Test of Sphericity Test was used to measures internal correlation of constructs or statements and the higher the value the better the results. If the associated probability is less than 0.05 , then the variables have some correlation to each other. This is what is required if the researcher has to find an underlying factor that represent the variables. Rusuli, Saufi, Tasmin, \&Hashim (2013) explained that KMO Measure of Sampling Adequacy should exceed 0.5 and for Bartlett's Test of Sphericity, the significant level of p- value should be less than 0.05 for Factor Analysis to be suitable.

\section{Kaiser-Meyer-Olkin (KMO) Measure and Bartlett's Test for Performance Variable}

\begin{tabular}{|l|c|c|}
\hline \multicolumn{2}{|c|}{ KMO Measure and Bartlett's Test } & 0.596 \\
\hline Kaiser-Meyer-Olkin Measure of Sampling Adequacy. & 293.458 \\
\cline { 2 - 3 } Bartlett's Test of Sphericity & Approx. Chi-Square & 6 \\
\cline { 2 - 3 } & Sig. & 0.000 \\
\hline
\end{tabular}

Table 2: Kaiser-Meyer-Olkin (KMO) Measure and Bartlett's Test for Performance Variable

The results in Table 2 show that the value of KMO Measure of Sampling Adequacy was found to be 0.596 and the Bartlett's Test of Sphericity had a significant p-value of less than 0.05, therefore study proceeded to Factor Analysis stage. Rusuliet al., (2013) explained that KMO Measure of Sampling Adequacy should exceed 0.5 and for Bartlett's Test of Sphericity, the significant level of p-value be less than 0.05 for Factor Analysis to be suitable.

\section{Communalities of the Items}

Communality indicates the amount of variance in each variable that is accounted for, i.e., the extent to which an item correlates with all other items. Initial communalities are estimates of the variance in each variable accounted for by all components or factors. Extraction communalities are estimates of the variance in each variable accounted for by the components. For principal components extraction, this is always equal to 1.0 for correlation analyses. Communality value is also a deciding factor to include or exclude a variable in the factor analysis. A value of above 0.5 is considered to be ideal. Hair et al., (2013) and Tabachnick \& Fidell (2007) recommends a cut off or threshold factor of 0.30 on factor loadings in determining the factors to be retained for further analysis. Factors loading with Eigenvalues greater than 0.5 should be extracted and those below 0.49 should not be considered.

\begin{tabular}{|c|c|c|}
\hline Communalities & Initial & Extraction \\
\hline $\begin{array}{l}\text { We have a self-rating system for our business unit's } \\
\text { overall market share objective }\end{array}$ & 1.000 & 0.743 \\
\hline $\begin{array}{l}\text { We enjoy a large market share with our products } \\
\text { sales }\end{array}$ & 1.000 & 0.645 \\
\hline The business has experienced customers royalty & 1.000 & 0.754 \\
\hline $\begin{array}{l}\text { The enterprise has experienced an increase on } \\
\text { average in daily sales }\end{array}$ & 1.000 & 0.582 \\
\hline
\end{tabular}

Table 3 show the four constructs has high communalities which indicates that the extracted components represent the variable well. They had factor loadings of between 0.754 and 0.582 . Due to the fact that that all the four constructs under the Performance variable had factor loadings of above the 0.5 , they were all retained and used in further analysis.

\section{Variance Explained}

In identifying the underlying factors, the following decision rules were used: first, factors needed latent root criterion (Eigenvalues) of 1.0 was used for factor inclusion and a factor loading of more than 0.50 used as a benchmark to include individual items for each factor. An Eigenvalues is the amount of variance that a particular variable or component contributes to the total variance. Second, the number of factors extracted should account for over $50 \%$ of the variance explained (Hair et al., 2013). The variance explained by the initial solution and the rotated components is displayed as shown in table 4. The first section of the table shows the Initial Eigenvalues.

The Total column gives the Eigenvalues, or amount of variance in the original variables accounted for by each component. The percent (\%) of Variance column gives the ratio, expressed as a percentage, of the variance accounted for 
by each component to the total variance in all of the variables. The Cumulative \% column gives the percentage of variance accounted for by the first $\mathrm{n}$ components. The principal component analysis was thus used for data reduction and interpretation of large set of data regarding variable of Performance in the study.

\begin{tabular}{|c|c|c|c|c|c|c|}
\hline \multicolumn{7}{|c|}{ Total Variance Explained } \\
\hline \multirow{2}{*}{ Component } & \multicolumn{3}{|c|}{ Initial Eigenvalues } & \multicolumn{2}{c|}{ Extraction Sums of Squared Loadings } \\
\cline { 2 - 6 } & Total & $\begin{array}{c}\% \text { of } \\
\text { Variance }\end{array}$ & $\begin{array}{c}\text { Cumulative } \\
\%\end{array}$ & Total & $\begin{array}{c}\% \text { of } \\
\text { Variance }\end{array}$ & Cumulative \% \\
\hline 1 & 2.724 & 68.096 & 68.096 & 2.724 & 68.096 & 68.096 \\
\hline \multicolumn{7}{|c|}{ Table 4: Total Variance Explained for Performance Variable } \\
\hline
\end{tabular}

Table 4 shows that, the single factor extracted accounted for 68.096 total variance of the variability in the original four components. All the remaining factors each controlled a very small portion of the total variance and their factors in total accounted for the remaining $31.904 \%$ of the variance which was negligible. The researcher considerably reduced the complexity of the data set by using this component, with only a $31.904 \%$ loss of information. Thus, only factor one which had Eigenvalues greater than one was considered for further analysis in the multiple regression. This factor was named Performance of dairy cottage industries.

\begin{tabular}{|l|c|}
\hline \multicolumn{1}{|c|}{ Opinion Statement } & Component \\
\hline $\begin{array}{l}\text { We have a self-rating system for our business unit's overall } \\
\text { market share objective }\end{array}$ & 0.862 \\
\hline We enjoy a large market share with our products sales & 0.803 \\
\hline The business has experienced customers royalty & 0.868 \\
\hline The enterprise has had an increase in average daily sales & 0.763 \\
\hline
\end{tabular}

Table 5: Component Matrix Method without Rotation for Performance Variable

Table 5 show all the constructs or statements under Performance variable had values more than 0.5 and therefore they were accepted and thus no statement was dropped. The four constructs that were considered had factor loadings of between 0.763 and 0.868 . Due to the fact that that all the four constructs under Performance variable had factor loadings of above the 0.5 , they were all retained and used in further analysis. Rotated Component Matrix was not done for the statements under the Performance variable because only one factor had Eigenvalues greater than one.

\section{Scree Plot}

The scree plot is a graphical tool used in determining the number of relevant components or factors to retain in factor analysis, and was proposed by Cattell (1966) and cited by Ledesma \& Valero-Mora (2007). With this procedure Eigenvalues are plotted against their ordinal numbers and one examines to find where a break or a leveling of the slope of the plotted line occurs. Tabachnick\&Fidell (2007), referred to the break point as the point where a line drawn through the points changes direction. The number of factors is indicated by the number of Eigenvalues above the point of the break. The Eigenvalues below the break indicate error variance.

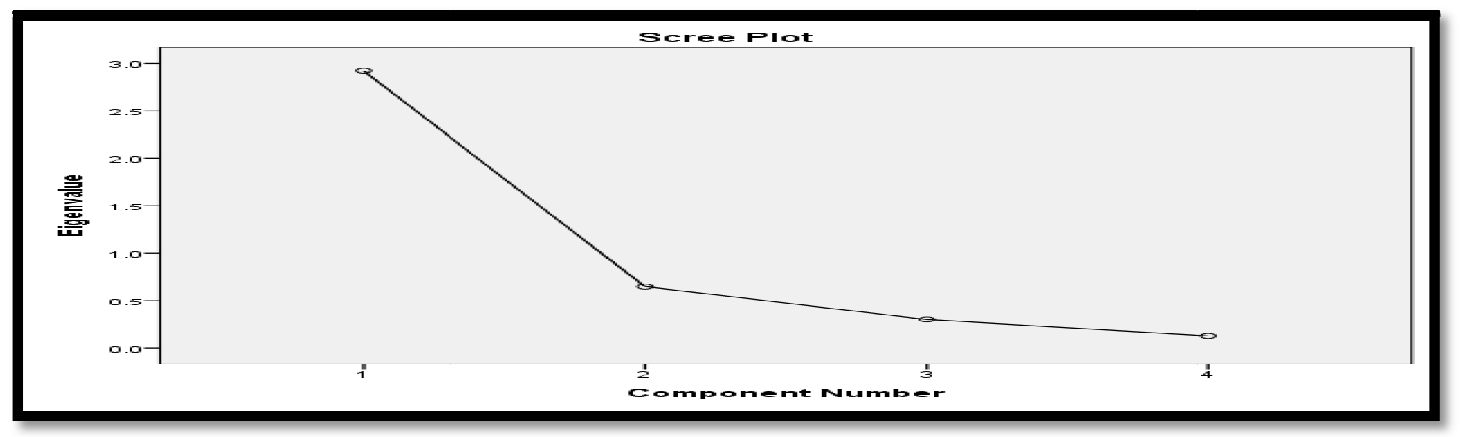

Figure 1: Scree Plot for Performance of Dairy Cottage Industries Variable

From figure 1 show there is only one factor with an Eigenvalues greater than one, hence this factor was named Performance of dairy cottage industries.

\section{Differentiation Strategy}

Kaiser-Meyer-Olkin (KMO) Measure and Bartlett's Test for Differentiation Variable 


\begin{tabular}{|l|c|c|}
\hline \multicolumn{2}{|c|}{ KMO Measure and Bartlett's Test } & 0.766 \\
\hline Kaiser-Meyer-Olkin Measure of Sampling Adequacy. & 610.470 \\
\cline { 2 - 3 } & Approx. Chi-Square & 15 \\
\cline { 2 - 3 } Bartlett's Test of Sphericity & df & 0.000 \\
\hline
\end{tabular}

Table 6: Kaiser-Meyer-Olkin (KMO) Measure and Bartlett's Test for Differentiation Variable

Table 6 results indicate that, factor analysis could be carried out as the KMO Measure of Sampling Adequacy was found to be 0.766 , the study proceeded to factor analysis stage. The Bartlett's Test of Sphericity result also show associated probability of less than 0.05 , indicating the variables have some correlation to each other, hence the researcher proceeded to factor analysis stage. Rusuliet al., (2013) explained that KMO Measure of Sampling Adequacy should exceed 0.5 and for Bartlett's Test of Sphericity, the significant level of $p$ value be less than 0.05 for Factor Analysis to be suitable.

\section{Communalities of the Items}

\begin{tabular}{|l|c|c|}
\hline \multicolumn{1}{|c|}{ Differentiation Statements } & Initial & Extraction \\
\hline \multicolumn{1}{|c|}{ Introduces innovative and unique products } & 1.000 & 0.924 \\
\hline Continuously developing new products & 1.000 & 0.862 \\
\hline Use superior packaging of products & 1.000 & 0.813 \\
\hline We always offer a broad range of products & 1.000 & 0.867 \\
\hline Offering unique customers experience & 1.000 & 0.968 \\
\hline Investing in research and development & 1.000 & 0.969 \\
\hline
\end{tabular}

Table 7: Communalities for Differentiation Variable

Table 7 show the six constructs or statements have high communalities which indicate that the extracted components represent the variable well. They had factor loadings of between 0.813 and 0.969 . Due to the fact that that all the six constructs or statements under differentiation variable had factor loadings of above the 0.5 , they were all retained and used in further analysis.

\section{Variance Explained}

Table 8 show the set of statements under the Differentiation variable where constructs were subjected to a variance test through the principal component analysis test.

\begin{tabular}{|c|c|c|c|c|c|c|}
\hline \multirow{2}{*}{ Component } & \multicolumn{3}{|c|}{ Initial Eigenvalues } & \multicolumn{3}{c|}{ Rotation Sums of Squared Loadings } \\
\cline { 2 - 7 } & Total & $\begin{array}{c}\text { \% of } \\
\text { Variance }\end{array}$ & $\begin{array}{c}\text { Cumulative } \\
\%\end{array}$ & Total & $\begin{array}{c}\text { \% of } \\
\text { Variance }\end{array}$ & $\begin{array}{c}\text { Cumulative } \\
\%\end{array}$ \\
\hline 1 & 3.845 & 64.077 & 64.077 & 3.421 & 57.021 & 57.021 \\
\hline 2 & 1.559 & 25.979 & 90.056 & 1.982 & 33.035 & 90.056 \\
\hline
\end{tabular}

Table 8: Total Variance Explained for Differentiation Variable

Table 8 shows all the factors that were extracted from the analysis along with their Eigenvalues. It was observed the first factor accounted for $64.077 \%$ of the total variance and the second $25.979 \%$. The remaining factors in total accounted for $9.944 \%$ of the remaining variance which was very negligible. Thus, only factor one and two which had an Eigenvalues greater than one were considered for further analysis in the multiple regression. These factors were named; brand image and products features, and service differentiation respectively. They explain nearly $90.056 \%$ of the variability in the original six constructs or statements, so the researcher can considerably reduce the complexity of the data set by using these components, with only a $9.944 \%$ loss of information. The rotation maintains the cumulative percentage of variation explained by the extracted components, but that variation is now spread more evenly over the components. The large changes in the individual totals suggest that the rotated component matrix is now easier to interpret than the un- rotated matrix.

\section{Scree Plot}

The scree plot result in Figure 2 indicates that two components had Eigenvalues that were greater than one. The finding corroborates the total variance explained results for Differentiation variable in Table 8. 


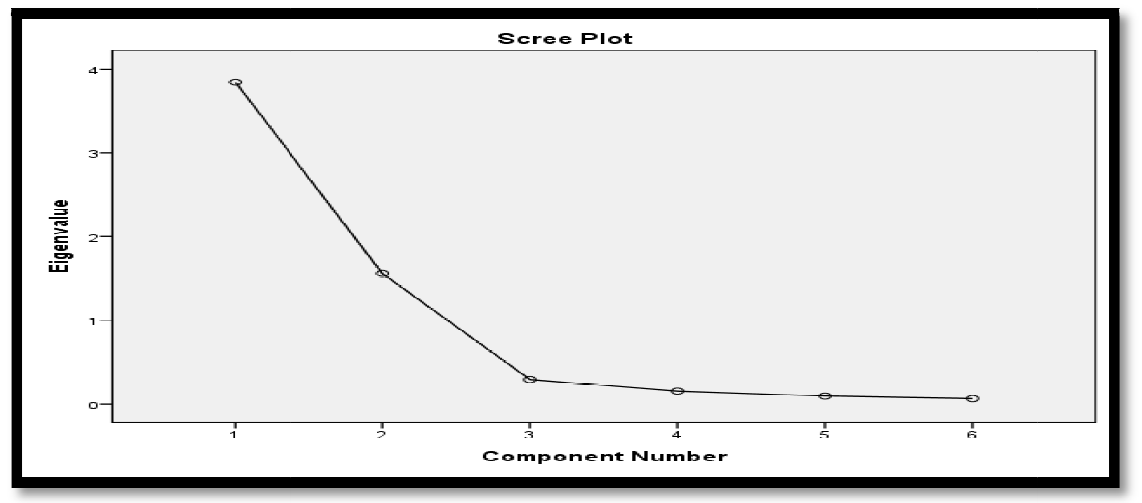

Figure 2: Scree Plot for Differentiation Variable

From figure 2 above show there are two factors with Eigenvalues greater than one. These factors were named; brand image and products features, and service differentiation.

\section{Diagnostic Tests}

\begin{tabular}{|c|c|c|c|}
\hline \multicolumn{2}{|c|}{ Variables } & $\begin{array}{c}\text { Performance of Dairy } \\
\text { Cottage Industries }\end{array}$ & $\begin{array}{c}\text { Differentiation } \\
\text { Strategy }\end{array}$ \\
\hline \multirow{3}{*}{$\begin{array}{l}\text { Performance of Dairy } \\
\text { Cottage Industries }\end{array}$} & Pearson Correlation & 1 & \\
\hline & Sig. (2-tailed) & & \\
\hline & $\mathrm{N}$ & 98 & \\
\hline \multirow[t]{3}{*}{ Differentiation strategy } & Pearson Correlation & $0.805^{* *}$ & 1 \\
\hline & Sig. (2-tailed) & 0.000 & \\
\hline & $\mathrm{N}$ & 98 & 98 \\
\hline
\end{tabular}

Table 9: Differentiation Strategy Linearity Test

Table 9 presents the results on the linearity association between differentiation strategy and performance of dairy cottage industries. The association between differentiation strategy and performance of cottage industries in Kiambu County was found to be 0.805 and the associated $p$-value was 0.000 , meaning that it was significant. This value was very high indicating a high positive linear association between the two variables. This association is supported by the finding of Gorton et al., (2013) whose findings argue in support of a linear association between differentiation strategy and firm performance.

\section{Regression Results}

\subsection{Differentiation Strategy and Performance of Dairy Cottage Industries}

- $\mathrm{H}_{1}$ : There was no significant relationship between Differentiation strategy and Performance of dairy cottage industries in Kiambu County.

\begin{tabular}{|c|c|c|c|c|}
\hline Model & R & R-Square & Adjusted R-Square & Std. Error of the Estimate \\
\hline & 0.602 & 0.802 & 0.800 & 0.36667 \\
\hline \multicolumn{6}{|c|}{ a. Predictors: (Constant), Differentiation strategy } \\
\hline
\end{tabular}

\section{Table 10: Model Summary}

Table 10 presents the R-Square and Adjusted R-Square test statistics for the test of the hypothesis; there was no significant relationship between Differentiation strategy and Performance of dairy cottage industries in Kiambu County. From the results the two tests were R-Square 0.802 or $80.2 \%$ shows that $80.2 \%$ performance of dairy cottage industries can be explained by differentiation strategy. The adjusted R-Square 0.800 or $80.0 \%$ indicates that differentiation strategy in exclusion of the constant variable explained the change in performance of dairy cottage industries by $80.0 \%$, the remaining percentage can be explained by other factors excluded from the model. The $\mathrm{R}$ of 0.602 shows there is a positive linear correlation between differentiation strategy and performance of dairy cottage industries. The standard error of estimate (0.36667) shows the average deviation of the independent variable from the line of best fit. The interpretation of this was that there was a linear positive association between differentiation strategy and performance of the dairy cottage industries in Kiambu County. 


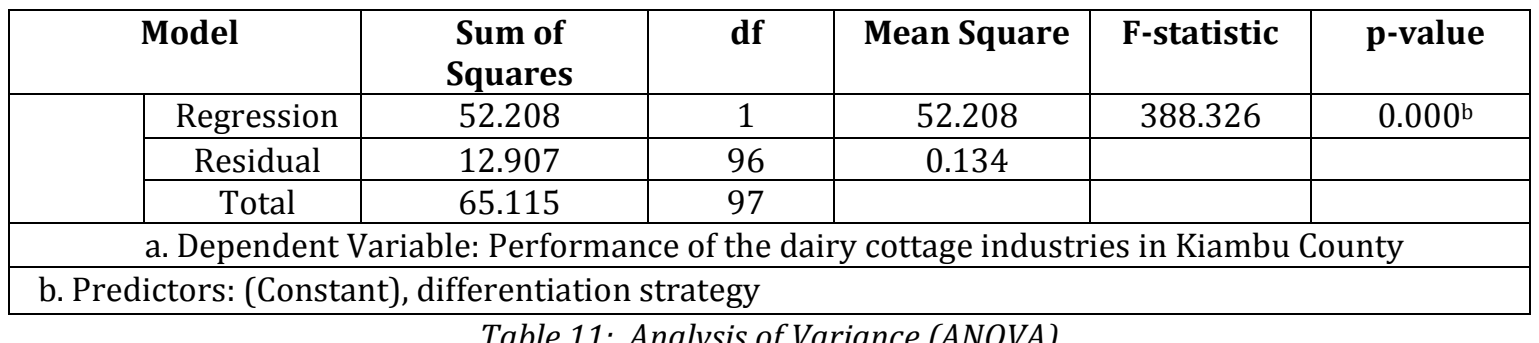

Table 11: Analysis of Variance (ANOVA)

Table 11 presents the F-statistics for the test of the hypothesis; there was no significant relationship between differentiation strategy and performance of dairy cottage industries in Kiambu County. From the results F-statistics had a value of 388.326 and the p-value was 0.000 . Since the p-value is less than 0.05 , it means that there exists a significant relationship between differentiation strategy and performance of dairy cottage industries. The interpretation of this was that there was a significant relationship between differentiation strategy and performance of the dairy cottage industries in Kiambu County.

\begin{tabular}{|c|c|c|c|c|c|}
\hline \multirow[t]{2}{*}{ Model } & \multicolumn{2}{|c|}{$\begin{array}{c}\text { Unstandardized } \\
\text { Coefficients }\end{array}$} & \multirow{2}{*}{$\begin{array}{c}\begin{array}{c}\text { Standardized } \\
\text { Coefficients }\end{array} \\
\text { Beta } \\
\end{array}$} & \multirow[t]{2}{*}{ t-statistic } & \multirow[t]{2}{*}{ p-value } \\
\hline & $\mathrm{B}$ & Std. Error & & & \\
\hline (Constant) & -0.071 & 0.197 & & -0.362 & 0.718 \\
\hline $\begin{array}{c}\text { Differentiation } \\
\text { strategy }\end{array}$ & 1.096 & 0.056 & 0.895 & 19.706 & 0.000 \\
\hline
\end{tabular}
Table 12: Coefficient Table

The fitted regression model is

$\mathrm{Y}=-0.071+1.096 \mathrm{X}_{1}$

Where; $\mathrm{Y}=$ Performance of dairy cottage industries, $\mathrm{X}_{1}=$ Differentiation strategy.

\section{Differentiation Strategy}

From table 12, the regression coefficient of Differentiation strategy was found to be 1.096. This value show that holding other variables in the model constant, an increase in Differentiation strategy by one unit causes Performance of dairy cottage industries to increase by 1.096 units. The positive association shows that there is significant positive relationship between differentiation strategy and performance of dairy cottage industry. This association is supported by the finding of Gorton et al., (2013) whose findings argue in support of a linear association between differentiation strategy and firm performance.

The coefficient was not just positive but also statistically significant with a t-statistics value of 19.706 . The standard error was found to be 0.056 and the p-value was found to be 0.000 . Since the p-value was less than 0.05 as shown in table 12, the null hypothesis was rejected and alternative hypothesis accepted. The interpretation was that Differentiation strategy causes Performance of dairy cottage industry to increase. The entrepreneurs should consider the significant relationship between differentiation strategy and performance of dairy cottage industries for the improvement of their firm performance. Moreover, a focus on making reliable and high-quality products will have a significant impact on sales, especially in more mature industries or in industries in which there is a high cost of poor performance (Wang et al., 2011). Firms that focus on differentiation often rely on product customization which, in turn, involves depending on close relationships developed with those customers. These close relationships overtime build the reputation of the firm (Banker et al., 2014). A good reputation translates into better performance and creates a valuable resource that is difficult to imitate thus providing the firm with a durable advantage. Product customization also involves the willingness of the firm to part with proprietary knowledge with suppliers. The sharing of such knowledge leads to more durable relationships since the firms need to rely on each other. The complex relationships that firm focusing on differentiation build with their customers and suppliers will be costly to duplicate and hence become a source of sustained competitive advantage (Banker et al., 2014). The study findings led to the rejection of the null hypothesis and acceptance of the alternative hypothesis that, there was a significant relationship between differentiation strategy and performance of dairy cottage industries in Kiambu County.

\section{Conclusions}

The study thus concludes that, there was a statistically significant relationship between differentiation strategy and performance of dairy cottage industries in Kiambu County. The study concludes that there is the need for businesses especially the ones in the dairy cottage industries to be keen on key constructs or statements of differentiation strategy such as; Introduces innovative and unique products; continuously developing new products; use superior methods for packaging of their products; offer a broad range of products to their customers; offering unique customers experience and investing in research and development. All these constructs or statements strongly supported the positive association of the differentiation strategy and performance of dairy cottage industries in Kiambu County, in Kenya. 
The hypothesis was tested by running a regressing of the differentiation strategy and performance of the dairy cottage industries in Kiambu County. From the correlation and the regression results it was concluded that, there was a significant relationship between differentiation strategy and performance of dairy cottage industries in Kiambu County. The study findings led to the rejection of the null hypothesis and acceptance of the alternative hypothesis that, there was a significant relationship between differentiation strategy and performance of dairy cottage industries in Kiambu County.

\section{Recommendations}

Since the results of this study revealed that differentiation strategy is an important aspect, this study recommends that the proprietors of the dairy cottage industries in Kiambu County should put some effort in improving the differentiation strategy aspect. The managers or the business owners in the cottage industry should ensure that; Introduces innovative and unique products; continuously developing new products; use superior methods for packaging of their products; offer a broad range of products to their customers; offering unique customers experience and investing in research and development are given priority as important tools of differentiation strategy. This study thus recommends that, managers or the business owners should ensure that the differentiation strategy is given priority in their dairy cottage industries routine operations, for improvement of dairy cottage industries performance.

\section{Suggestions for Further Research}

The study recommends further research on strategic management, attentively to strategic behavior of cottage industries in developing economies in an effort to know the universality of competitive strategies theories.

\section{References}

i. Agyapong, A., Ellis, F., \&Domeher, D. (2016). Competitive strategy and performance of family businesses: moderating effect of managerial and innovative capabilities. Journal of Small Business \& Entrepreneurship, 28(6), 449-477.

ii. Akporhonor, B. A., \&Akpojotor, L. O. (2016). Challenges confronting postgraduate library and information science student in the use of electronic resources in Southern Nigeria. Library Philosophy and Practice, 0_1.

iii. Ali, A., Namusonge, G. \&Sakwa, M. (2016). Effect of firm managerial risk aversion on corporate hedging of listed firms in Nairobi Securities Exchange in Kenya. IJRDO - Journal of Business Management, 2(7), 45-64.

iv. Aluvala, R. (2017). Millennial workforce: A contemplation. Hyderabad, India: Zenon Academic Publishing.

v. Atikiya, R., Mukulu, E., \&Waiganjo, E. (2015). Effect of cost leadership strategy on the performance of manufacturing firms in Kenya. Strategic Journals, 2(8), 134-143.

vi. Awaluddin, M., Sule, E. T., \&Kaltum, U. (2016). The Influence of Competitive Forces And Value Creation On Company Reputation And Competitive Strategy: A Case Of Digital Creative Industry In Indonesia With The Implication On Sustainable Business Performance. International Journal of Social economics, Commerce and Management, 4(2), 201-234.

vii. Banker, R. D., Mashruwala, R., \&Tripathy, A. (2014). Does a differentiation strategy lead to more sustainable financial performance than a cost leadership strategy?.Management Decision, 52(5), 872-896.

viii. Becerra, M., Santaló, J., \& Silva, R. (2013). Being better vs. being different: Differentiation, competition, and pricing strategies in the Spanish hotel industry. Tourism Management, 34, 71-79.

ix. Bornstein, M. H., Jager, J., \&Putnick, D. L. (2013). Sampling in developmental science: Situations, shortcomings, solutions, and standards. Developmental Review, 33(4), 357-370.

x. Bouazza, A. B. (2015). Small and medium enterprises as an effective sector for social economic development and employment creation in Algeria. International Journal of Social economics, Commerce and Management, 3(2), 116.

xi. Burns, R. P., \& Burns, R. (2008). Business research methods and statistics using SPSS. Sage.

xii. Cattell, R. B. (1966). The screen test for the number of factors. Multivariate behavioral research, 1(2), $245-276$.

xiii. Coakes, S. J. (2013). SPSS 20.0 for Windows-Analysis without Anguish. Australia.

xiv. Dirisu, J. I., Iyiola, O., \&Ibidunni, O. S. (2013). Product differentiation: A tool of competitive advantage and optimal organizational performance (A study of Unilever Nigeria PLC). European Scientific Journal, ESJ, 9(34), $258-281$.

xv. Gichinga, W. L., Mukulu, E., \&Mwachiro, S. (2014). Use of academic staff performance appraisal to attain competitive advantage: A comparative study of Kenyan universities. European Journal of Business Management, 1(11), 140-187.

xvi. Gorton, M., Hubbard, C., \&Fertö, I. (2013). International comparison of product supply chains in the agri-food sector: Determinants of their competitiveness and performance on EU and international markets. Germany: Leibniz Institute of Agricultural Development in Transition Economies (COMPETE Project Coordination, No 3).

xvii. Groves, R. M., Fowler Jr, F. J., Couper, M. P., Lepkowski, J. M., Singer, E., \&Tourangeau, R. (2011). Survey methodology (Vol. 561).John Wiley \& Sons.

xviii. Hair, J. F., Black, W. C., Babin, B. J., Anderson, R. E., \&Tatham, R. L. (2013). Multivariate Data Analysis: Pearson Education Limited.

xix. Hemedi, K. (2019). The Impact of Customer Retention Strategies to the Performance of Dairy Industry in Tanzania: A Survey Study of Dairy Producers Companies of Southern Highland in Tanzania (Doctoral dissertation).

xx. Hossain, M. M., \& Imran, S. M. (2019). Analysis of Cottage Industry in Bangladesh: A case study on Khadi. International Journal of Science and Business, 3(1), 118-125. 
xxi. Hoyer, W. D., MacInnis, D. J, \&Pieters, R. (2013). Consumer behavior (6th ed.). Mason, OH: Cengage Learning.

xxii. Joy, D. M. T., \&Kani, R. M. (2013). Emerging opportunities and challenges for cottage industries in India. International Journal of Scientific and Research Publications, 3(3), 1-4.

xxiii. Kariuki, A. N. (2016). Influence of Product Diversification Drivers on Performance of Dairy Enterprises in Kenya (Doctoral dissertation, Business Administration (Strategic Management), JKUAT).

xxiv. Kebede, A. M. \&Tegegne, Z. L. (2018). The effect of customer relationship management on bank performance: In context of commercial banks in Amhara Region, Ethiopia. Cogent Business \& Management, 5: 1-9.

xxv. Kenya National Bureau of Statistics. (2016). Micro, Small and Medium Establishment (MSME) Survey: Basic Report. Nairobi: KNBS. Available online at: https://www.knbs.or.ke/download/2016-msme-basic-report/

xxvi. Khan, N. (2018). Critical Review of Cottage and Small Scale Industries in Pakistan. Critical Review, 8(3).

xxvii. Kinyuira, D. (2014). Effects of Porter's Generic competitive strategies on the performance of Savings and Credit Cooperatives (Saccos) in Murang'a County, Kenya. IOSR Journal of Business and Management, 16(6), 93-105.

xxviii. Kotelnikov, V. (2013). Differentiation strategy: How to survive in the era of hypercompetition. White paper, Givis, Dover, DE.

xxix. Kothari, C. R. (2013). Research methodology: Methods and techniques (3 ${ }^{\text {rd }}$ Revised Edition). New Delhi: New Age International.

xxx. Krejcie, R. V., \& Morgan, D. W. (2016). Determining Sample Size for Research Activities. Educational and Psychological Measurement.30, 607-610.

xxxi. Kusi, A., Opata, C. N., \&Narh, T. W. J. (2015). Exploring the factors that hinder the growth and survival of small businesses in Ghana (a case study of small businesses within Kumasi Metropolitan area). American Journal of Industrial and Business Management, 5(2), 705-723.

xxxii. Ledesma, R. D., \& Valero-Mora, P. (2007). Determining the number of factors to retain in EFA: An easy-to use computer program for carrying out parallel analysis. Practical Assessment, Research \& Evaluation, 12(2), 1-11.

xxxiii. Lee, J.L., Jeffrey, D.J. \& Kim, Y.K. (2014). A re-conceptualization of brand image. International Journal of Business Administration, 5 (4): 1-11.

xxxiv. Makokha, P. M. (2014). The place of home-based industries in rural Kenya's socio-social economic progress: A case study of Kakamega County. Journal of Social economics and Sustainable Development, 5(28), 154-173.

xxxv. Makokha, P. M. (2015). Impediments to the growth of cottage industries in Kakamega County, Kenya. Developing Country Studies, 5(2), 106-125.

xxxvi. Mbugua, S. K., Njeru, A., \&Tirimba, O. I. (2014). Factors affecting the performance of small and micro enterprises in Limuru Town Market of Kiambu County, Kenya. International Journal of Scientific and Research Publications, $4(12), 1-20$.

xxxvii. Muthui, J. N., Mshenga, P. M., \&Bebe, B. O. (2014). The influence of livestock market structure conduct and performance on herd productivity among smallholder dairy farmers in Western Kenya. Journal of Agricultural Social economics and Development, 3(1), 12-16.

xxxviii. Mwangi, E. W., \&Ombui, K. (2013). Effects of competitive strategies on the performance of mission hospitals in Kenya: A Case of Kijabe Mission Hospital. International Journal of Science and Research, 2(11), 14-19.

xxxix. Nagar,N. \& Solanki,M.(2015). Challenges Faced by Small Scale and Cottage Industries. International Business Journals. Issue 15 March 2015 ISSN 2348 - 4063.

xl. Nassiuma, D., \&Nyoike, N. (2014). Milk production and marketing in Kenya: A preliminary survey 2013 Report.

xli. Neuman, W. L. (2013). Social research methods: Qualitative and quantitative approaches. Pearson education.

xlii. Nguyen, H. \&Gunasti, K. (2018). Original brands in competition against high quality copycats. European Journal of Marketing, 52(7/8): 1574-1597.

xliii. Pandey, V. (2013). Trends, Opportunities \& Challenges in Small Scale and Cottage Industries in Uttar Pradesh. Asian Journal of Technology \& Management Research, 3(2), 2249 -0892.

xliv. Porter, M. (1980). Techniques for analyzing industries and competitors, Competitive Strategy. New York: Free Press.

xlv. Porter, M. E. (1985). Competitive advantage: Creating and sustaining superior performance, New York: The Free Press.

xlvi. Pourhosseini, A., \&Shahrokh, Z. D. (2013). The Effect of Marketing Strategy on Sales Performance: The Moderating Effects of Internal and External Environment. World Applied Sciences Journal, 26 (1), 28-33.

xlvii. Rahman, M. T., \& Kumar, D. (2018). Problems and prospects of cottage industry in Khulna division of Bangladesh: An empirical assessment. IOSR Journal of Business and Management, 20(6), 45-52.

xlviii. Rahmani, Z., \&Mousavi, S. A. (2011). Enhancing the innovation capability in the organization: A conceptual framework. Proceedings of the $2^{\text {nd }}$ International Conference on Education and Management Technology, IPEDR vol.13 (2011), p. 285-291.

xlix. Rusuli, C., Saufi, M., Tasmin, R., \&Hashim, N. (2013). Factor retention decisions in exploratory factor analysis results: A study type of knowledge management process at Malaysian university libraries. Asian Social Science Journal, 9(15).

1. Tabachnick, B. G., \&Fidell, L. S. (2007). Using multivariate statistics (5th ed.). New York: Allyn and Bacon.

li. Tasneem, S., \& Biswas, R. (2014). Role of cottage industry in the social economic development of Bangladesh: An empirical study. Journal of Business and Management, 16(10), 10-18.

lii. Trotter II, R. T. (2012). Qualitative research sample design and sample size: Resolving and unresolved issues and inferential imperatives. Preventive medicine, 55(5), 398-400. 
liii. Utami, S. (2015). The Influence of Customers" Trust On Customer Loyalty. International journal of social economics, commerce and management, 3(7), 638-653.

liv. Wambugu, S., Kirimi, L., \&Opiyo, J. (2011). Productivity trends and performance of dairy farming in Kenya. Tegemeo Institute of Agricultural Policy and Development.

lv. Wang, W. C., Lin, C. H., \& Chu, Y. C. (2011). Types of competitive advantage and analysis. International Journal of Business and Management, 6(5), 100. 